\title{
Redaksioneel
}

\section{Die toekoms van Chemie aan universiteite}

Indien 'n departement aan 'n universiteit doelwitbeplanning doen of aksieplanne beraam, moet dit natuurlik geskied teen die agtergrond van geleenthede wat die vak bied en die behoeftes van die gemeenskap in diens waarvan die departement staan. Geen departement kan dit egter bekostig dat sy akademiese aktiwiteite net so gerig word om aan die behoeftes van die gemeenskap te voldoen nie. Die soeke na waarheid wat hom deur basiese navorsing manifesteer, moet natuurlik binne 'n departement die oorheersende motivering wees vir intellektuele vryheid. Indien daar na Chemie gekyk word en meer spesifiek hoe Chemie aan 'n Suid-Afrikaanse universiteit doseer word, kan so 'n departement hom egter nie heeltemal losmaak van die geleenthede wat daar in die vak bestaan, of die behoeftes van die gemeenskap nie. Om die opleiding van studente of navorsing binne ' $n$ departement te beplan en uit te voer sonder die inagneming van nuwe ontwikkelings in die vak en veral ont wikkelings wat van waarde is vir die gemeenskap, is 'n gevaarlike mistasting. 'n Mens kan egter tereg vra wat die geleenthede en behoeftes van Chemie is, m.a.w. wat hou die toekoms vir 'n Chemiedepartement aan 'n universiteit in.

Onlangs het 'n boek, "Enough of Pessimism", deur Philips H. Abelson ${ }^{1}$ verskyn. Abelson was vir 22 jaar redakteur van die invloedryke tydskrif "Science". Hy is dus in 'n uitstekende posisie om 'n oorsig te gee van ontwikkelings op die gebied van wetenskappe die afgelope 22 jaar en ek haal aan wat hy van Chemie in hierdie boek sê: "Of all the sciences, chemistry has been the most ineffective in its public relations. This has not been owing to some defect in the character of chemists or their leadership, but rather to special circumstances. As the enormous extent of the changes in society and of society's dependence on science becomes more apparent, chemistry will emerge as the star performer."

Chemie is 'n sentrale wetenskap, en selfs miskien dié sentrale wetenskap, soos ook baie duidelik geblyk het uit die nou reeds beroemde en gesaghebbende Pimentelverslag wat in 1985 in die VSA verskyn het oor "Opportunities in Chemistry". ${ }^{2}$ Benewens die feit dat dit die sentrale wetenskap is, is Chemie ook enorm in omvang en beleef ' $n$ ongekende groei. Hierdie groei word onder andere gereflekteer deur opnames wat gemaak word van die aantal publikasies wat per jaar in sekere vakgebiede verskyn. Chemie, insluitende Biochemie en Chemiese Ingenieurswese, het byvoorbeeld 4,5 miljoen publikasies gedurende 1969-1982 gelewer en groei teen 'n tempo van 35000 publikasies per maand. ${ }^{3}$ Dit vergelyk gunstig met die naaste mededinger, $\mathrm{nl}$. alle biologiese wetenskappe, wat 3,3 miljoen publikasies gedurende dieselfde tyd opgelewer het en groei teen 'n tempo van 23000 publikasies per maand. ${ }^{4}$

Chemie in sy rol as sentrale wetenskaprigting kom nie altyd tot sy reg in 'n universiteit in Suid-Afrika nie; of anders gestel: die grootte (uitgesonderd dienskursusse) en vitaliteit van Chemiedepartemente reflekteer nie altyd die grootte en belangrikheid van die vakgebied nie. Dit is egter nie 'n verskoning om altyd te verwys na chemici se agterstand op professionele gebied nie, hoe geldig so 'n rede ook mag wees. ' $n$ Mens kan vra of chemici genoeg doen om hulle vak bekend te stel, en dit veral in die lig van die sentrale rol wat hulle vak speel. By universiteite waar Mediese Fakulteite gevestig is, kan veel gedoen word om die rol wat Chemie ook hier in navorsing speel, te beklemtoon en veral ook die wondere wat verrig kan word met moderne meetinstrumente soos KMR- en ander spektrometers, asook die beklemtoning van $\mathrm{X}$-straalstruktuurbepalings. Die regverdiging vir Chemie se bestaan is beslis nie geleè in die dienste wat hy aan ander vakgebiede kan lewer nie. Maar om sy sentrale rol te regverdig moet chemici betrokke raak, byvoorbeeld by pogings wat nuwe medikasies teen 'n wye verskeidenheid van siektes soos kanker ontwikkel, die ontwikkeling van chemikalieë vir die landbou (bv. veilige en biologies-afbreekbare swamdoders) en in die ontwerp van byvoorbeeld plastiekmateriale waar 'n kennis van Chemie, en van chemiese binding in die besonder, van oorheersende belang is. Binne die Suid-Afrikaanse konteks is materiale en minerale baie belangrik en kan 'n mens die vraag vra of enige program op die gebied van materiale sal slaag as ' $n$ chemikus nie daarin 'n prominente rol speel nie. Die antwoord is nee, veral nie as 'n mens kyk na die ontwikkelings in die VSA waar vastetoestandchemici en -fisici sy aan sy werk met ingenieurs in gevorderde navorsingsprojekte wat te make het met die ontwikkeling van nuwe materiale nie.

Dit is natuurlik so dat die agterstand wat 'n chemikus op die gebied van professionele status en vergoeding teenoor byvoorbeeld die mediese beroep en ingenieurswese het, die gewildheid van die vak onder studente strem, en veral die gehalte van studente benadeel. Dit is veral jammer in ' $n$ land soos Suid-Afrika waar Chemie 'n besondere rol het om te vervul, nie net op die gebied van die ontwikkeling en oordrag van hoëvlaktegnologie nie, maar ook wat die ontwikkeling van hulpbronne betref, wat die land potensieel een van die rykstes maak. Dit is egter my oortuiging dat belowende studente nie net ingestel is op vergoeding nie, maar dikwels ook die kanse op sukses in 'n beroep deeglik oorweeg. Indien 'n chemikus suksesvolle bydraes tot die ontsluiting van die rykdomme van hierdie land kan maak, sal sy 
belangrikheid onder ingenieurs, metallurge, geoloë en ander wetenskaplikes so vanselfsprekend aanvaar word, dat die status van sy beroep onmiddellik sal verhoog.

Is die keuse van navorsingsgebiede in Chemie nie soms uiters verbeeldingloos aan S.A. universiteite nie? Kan 'n mens werklik dit regverdig dat navorsing op totaal irrelevante onderwerpe binne die SuidAfrikaanse situasie onderneem word, terwyl daar soveel uitdagende probleme lê en wag? Let wel, daar word nie gepleit vir toegepaste werk by universiteite nie, maar wel vir ' $n$ sekere persentasie gerigte basiese projekte wat 'n kans op sukses het en dan ook moontlik ' $n$ bydrae kan lewer tot die behoeftes van die gemeenskap waarbinne ons leef. Suksesse hier sal veel meer bydra tot 'n verhoging van die belangrikheid en status van 'n chemikus as al die vertoë vanaf openbare verhoë en die opstel van memorandums oor die professionele agterstand van chemici.

Indien Chemie so geweldig groei soos dit uit die jaarlikse toename in publikasies blyk, stel dit ook besondere eise aan chemici om op die hoogte van ontwikkelings te bly. Dit bring ook 'n dilemma mee vir Chemiedepartemente wat moet besluit om te rasionaliseer en te spesialiseer. Die rasionalisasie van navorsingsprojekte is natuurlik altyd gewens, maar 'n enkele navorsingsgebied binne 'n Chemiedepartement is nie moontlik as daar na die omvang van die vak gekyk word nie. So 'n situasie kan ook veroorsaak dat studente 'n baie ongebalanseerde opleiding in Chemie ontvang. Aan die ander kant is dit ook nie moontlik om alle belangrike velde in Chemie met navorsingsrigtings te dek nie, en dit is veral hier waar geleenthede en behoeftes as 'n baie duidelike riglyn gebruik kan word. Fondse moet natuurlik ook beskikbaar wees om navorsingsgebiede sinvol te kan onderneem, en dit is dan ook een van die primêre oorwegingsredes in die keuse van navorsingsvelde. Persone wat die leiding in Chemiedepartemente gee, moet veral op die hoogte bly van ontwikkelings binne die vak Chemie om navorsingsuitsette en -projekte te kan evalueer en navorsingsprojekte in die departement te kanaliseer, sodat geleenthede na behore benut word.

Vroeër is verwys na wat Abelson gesê het oor die beeld van ' $n$ chemikus. Dit tref enige dosent aan 'n Chemiedepartement hoe negatief studente veral in dienskursusse teenoor Chemie ingestel is. Hierdie studente beklee later heel dikwels belangrike betrekkings in hulle professionele lewe en word hierdie negatiewe houding sodoende versterk by beleidmakers. Baie besware kan ingebring word teen die aanbieding van dienskursusse en die feit dat Chemie oënskynlik nie van direkte toepassing in sekere beroepe is nie. As 'n mens egter enigsins verdere ondersoek instel, is dit duidelik dat die negatiewe houding teenoor Chemie in die skole ontstaan. Die opleiding in Chemie onder skoliere is dan ook 'n groot bron van kommer. Soos aangedui, is Chemie 'n enorme groot vakgebied, maar op skoolvlak word dit saamgevoeg met Fisika en heel dikwels, vanweë die beter werksgeleenthede in Chemie, deur onderwysers aangebied wat hoofsaaklik in Fisika opgelei is. Daar is geen twyfel oor die belangrikheid van Chemie vir 'n nywerheidsland nie, veral in Suid-Afrika waar baie werksgeleenthede geskep moet word. Daarom is die opleiding van Chemie onder skoliere werklik kommerwekkend. Chemie sal ook aan alle bevolkingsgroepe onderrig moet word en dit is veral hier waar 'n groot geleentheid vir Chemie bestaan. Om Chemie te doseer aan studente wat 'n agterstand op opvoedkundige gebied gehad het, gaan nuwe uitdagings bring vir Chemiedepartemente en sal onderrigontwikkeling in Chemie ook sy regmatige aandeel moet kry. Oorbruggings- of deurgangskursusse sal ontwerp moet word en daar sal veral oor die aanbieding van praktika besin moet word. Vir etlike jare vind die ontwikkelings in Chemie so vinnig plaas dat 'n driejarige B.Sc.-graad nie meer voldoende is as opleidingskwalifikasie vir chemici nie. Indien so 'n graad met albei hoofvakke in Chemie aangebied word, ontneem dit weer die student die geleentheid om behoorlike agtergrondkennis te verkry in belangrike aanvullende vakke soos Wiskunde, Fisika, Rekenaarswetenskap en ander. Dit is in elk geval nie gewens dat universiteite studente in 'n driejarige graad in Chemie oplei, maar wat nie deur die S.A. Raad vir Natuurwetenskaplikes vir registrasie aanvaar word nie. 'n Vierjarige graad, soos by Ingenieurswese, is dus ' $n$ minimumvereiste vir 'n behoorlik opgeleide chemikus, en daar kan gerus ook gekyk word na die moontlikheid om dit verpligtend te maak vir so 'n student om sy opleiding aan 'n universiteit aan te vul met praktiese ondervinding in 'n nywerheid of navorsingsinrigting.

Ten slotte kan niemand twyfel aan die toekoms van Chemie by universiteite nie. "Nuwe" en uitdagende navorsingsrigtings soos Biotegnologie en Materiaalwetenskappe kan net behoorlik by universiteite ontwikkel word indien die chemikus ook' $n$ rol daarin speel. Die brugvormende rol wat 'n chemikus tussen die Wiskundige Wetenskappe en Fisika aan die een kant en die Biologiese Wetenskappe aan die ander kant speel, gee hom 'n unieke geleentheid in die ontwikkeling van vele nuwe navorsingsvelde. Sy kennis van sintese en van chemiese binding maak dat sy bydrae uniek en van kardinale belang in gemeenskaplike navorsingsrigtings is. Baie tegnologiese ontwikkelings hang ook baie af van die insette wat chemici maak. In die lig van bostaande kan Chemie 'n groot en belangrike toekoms hê, maar dit is uiters noodsaaklik dat Chemiedepartemente en chemici hulle vak se swak openbare beeld sal probeer regstel en veral hulle aktiwiteite so sal beplan en uitvoer, dat die sentrale rol van Chemie op alle terreine sterk na vore sal tree. Dit vereis weer dat strukture binne Chemiedepartemente ingrypend verander moet word om voorsiening te maak vir onderrig en navorsing in nuwe rigtings wat in Chemie ontwikkel en dat die personeel wat Chemie doseer, behoorlik opgelei is en aktief navorsing bedryf, sodat hulle aan die eise van die nuwe uitdagings kan voldoen. 
Departement Chemie, Universiteit $\begin{gathered}\text { A.M. Heyns } \\ \text { van Pretoria, } \\ \text { Pretoria } 0002\end{gathered}$

VERWYSINGS

1. Abelson, P.H. (1986). Enough of Pessimism McGraw-Hill,
New York).

2. Pimentel, G.C. (1985). Opportunities in Chemistry (National Academy Press, Washington (DC)).

3. Chemical Abstracts Search, 3460 Hillview Ave, Palo Alto, CA 93304 USA

4. Biosis Previews, Biosciences Information Service, 2100 Arch Street, Philadelphia, PA 19103, USA.

\section{Termomskrywings}

Omdat outeurs nie altyd weet wat met die terme navorsingsbrief, navorsingsartikel en oorsigartikel bedoel word nie, word hier 'n kort omskrywing van hierdie terme gegee:

- 'n Navorsingsbrief is 'n kort bekendstelling van navorsing waarmee die outeur besig is, of wat pas afgehandel is. Dit kan 'n uitgebreide navorsingsartikel oor die betrokke onderwerp voorafgaan.
- 'n Navorsingsartikel behandel 'n meer uitgebreide en afgeronde stuk navorsingswerk en sluit 'n kritiese bespreking van die resultate in.

- 'n Oorsigartikel is 'n kritiese verslag van navorsing en kundigheid in 'n gespesialiseerde gebied, gerig op vakgenote. 